\title{
Medicinal plants and other botanical products from the Brazilian Official Pharmacopoeia
}

\author{
Maria G. Lins Brandão ${ }^{1 *}$, Gustavo P. Cosenza ${ }^{1}$, Raquel Assis Moreira ${ }^{1}$, \\ Roberto L.M. Monte-Mor ${ }^{2}$ \\ ${ }^{1}$ Pharmacy Faculty, Federal University of Minas Gerais, Av. Antônio Carlos, 6627, \\ 31270-901, Belo Horizonte, MG, Brazil, \\ ${ }^{2}$ Economic Sciences Faculty, Federal University of Minas Gerais, Av. Antônio Carlos, 6627, \\ 31270-901, Belo Horizonte, Brazil
}

\begin{abstract}
RESUMO: "Plantas medicinais e outros produtos vegetais da Farmacopéia Brasileira". Este artigo descreve os resultados de uma extensa revisão efetuada nas quatro edições da Farmacopéia Brasileira, buscando dados sobre as plantas medicinais e outros produtos vegetais nela descritos. $\mathrm{O}$ crescimento da indústria farmacêutica internacional a partir da segunda metade do século passado afetou intensamente a medicina oficial no Brasil. O texto faz uma breve análise das transformações sofridas pela Farmacopéia, tomando como base a existência de Monografias para as espécies vegetais nativas. Os resultados do estudo demonstram uma intensa substituição das plantas nativas do Brasil por medicamentos industrializados e outros produtos vegetais estrangeiros, confirmando assim a necessidade de investimentos em pesquisa de validação das nossas plantas medicinais.
\end{abstract}

Unitermos: Farmacopéia Brasileira, plantas medicinais, Brasil.

\begin{abstract}
In this paper, we describe the results of a thorough survey in the four editions of the Brazilian Official Pharmacopoeia (FBRAS), in a search for data about the plants and other botanical products included in them. The growth of the pharmaceutical industry since the second half of last century markedly affected the Brazilian official medicine. The paper analyses the transformation within the Pharmacopoeia, focusing on the presence of Monographs for Native medicinal plants. The result showed a strong substitution of Native American medicinal plants by industrialized medicine and foreign medicinal plants in FBRAS and confirms the necessity of investiments in research for the validation of Brazilian Native plants.
\end{abstract}

Keywords: Official Pharmacopoeia, medicinal plants, Brazil.

\section{INTRODUCTION}

In 2001, the Council of Genetic Heritage of Brazil's Ministry of the Environment and Renewable Natural Resources (Conselho de Patrimônio Genético do Ministério do Meio Ambiente e Recursos Naturais Renováveis - CGEN/MMA) instituted a decree (2.186$16 / 2001$ ) establishing a series of regulatory norms for the collection and bioprospection of medicinal plants in the country. Such a decree responded to a recommendation by the Biological Diversity Convention (Convenção da Diversidade Biológica - CDB) and it was considered necessary in the face of the growing interest on products related to the Brazilian biodiversity and of the need to share with traditional populations the profits derived from their commercial exploitation.

In April 2006, our research group (GEPLAMTUFMG) wrote a report for the Public Attorney (Ministério Público) of the state of Minas Gerais about the current situation of the native plants that are commonly used in this state's traditional medicine, in an attempt to verify if they require some kind of legal protection (see www. mp.mg.gov.br). More recently, the Federal Government made public, through the Ministry of Development, Industry and Foreign Commerce, a list of three thousand plants and botanical products for legal protection against foreign patents. All these measures aim to establish forms of protective actions for the country's biodiversity and traditional medicine, which is still quite unkown.

In this study, we present a list of the medicinal plants and other botanical products described in the four Editions of the Brazilian Official Pharmacopoeia (FBRAS) (Pharmacopoeia dos Estados Unidos do Brasil, 1926; Farmacopeia Brasileira, 1959; Farmacopeia Brasileira, 1977; Farmacopeia Brasileira, 1988-1996). The objectives of this study are to contribute for the protection of the native species included in the FBRAS, and to guide Brazilian researches in perfor ming validation studies for them. 


\section{METHODS}

The Brazilian Official Pharmacopoeia (FBRAS) has three older Editions published in 1926, 1959, 1977 and the newest Edition published since 1988. Each edition of FBRAS was carefully revised by us in order to obtain data about the described medicinal plants and other botanical products. Each pharmaceutical product is described in the Pharmacopoeias in the form of Monographs. For herbal products, the Monographs include data about botanical, physical-chemical and chemical analysis. From the Monographs, we extracted data about popular and scientific names of each species, their botanical Families, the part of the plant used, and the type of medicine described for each one in the four different Editions: vegetal drug (vd), tincture (tn), fluid extracts (fe), oils, essencial oils (es), dry extracts (ex) and other forms. All the results were organized in Table 1.

The names of each species and their Botanical Families were updated with data researched in the site of the Missouri Botanical Garden (www.mobot.org). For those species whose names were not found in that site, we maintained the name as described in the FBRAS. References about the geographic origin were obtained from classical literature in the Pharmacognosy area such as Gilg et al. (1942), Youngken (1943), Golse (1955), Casamada (1977), Costa (1996) as well as in hystoric bibliography that described the use of medicinal plants in Minas Gerais in the nineteenth century (Burton, 1977; Dean, 1996; Figueiredo, 2002; Godoy, 1996; Mawe, 1978; Pohl, 1976; Saint-Hilaire, 1974; Silva, 1997; Spix, 1981). Native species from Brazil are indicated in Table 1 with an '*'.

\section{RESULTS AND DISCUSSION}

In this study, we have performed an extensive revision within the FBRAS editions to verify all the medicinal plants and botanical products there described, looking at a total of 985 Monographs. The Monographs are for 321 different species, distributed in 98 Botanical Families. Table 1 shows the described plant and products, their respective popular and scientific names, Botanical Families, the part(s) used for pharmaceutical forms in each Edition of FBRAS. Several plants are intensively used for preparation of medicine as Digitalis and Cinchona species but others, such as Erytroxylum coca, Cannabis sativa or Colchicum automnale, do not have any significant importance as sources of medicines.

The First Edition of FBRAS, published in 1926, includes 1702 Monographs for medicinal products. Among those, 713 Monographs (42\%) refer to medicinal plants (228 for vegetal drugs and 83 for powdered drug) and products obtained from extraction: 167 Monographs for fluid-extracts (fe), 108 Monographs for tinctures (tn), 59 Monographs for dry extracts (ex), 40 for essential oils, 10 for oils and 18 for other products. That edition was published at a time when medicine preparation was predominatly based on natural products and plants were still the main source of materials for those products. The Second Edition was published in 1956 and includes 814 Monographs. From those, $193(23,7 \%)$ refer to medicinal plants and other botanical products. That edition came out soon after the Second World War, a period in which several synthetic medicines were developed. At that time, an accelerated expansion of pharmaceutical production also began in Brazil with the establishment of multinational pharmaceutical companies in the country. In 1977 the Brazilian Government published the Third Edition of FBRAS including 471 Monographs for medicinal products, but the number of Monographs for medicinal plants and botanical products was strongly reduced to only $23(4,8 \%)$. That edition does not have any Monographs for fluid-extracts, tinctures and other products from extraction of vegetal drugs. The period was characterized by a strong wave of industrialization in Brazil and by the consolidation of foreign pharmaceutical companies within the country. The Fourth and last Edition includes, until today, only 44 Monographs for medicinal plants and botanical products. Our results show how plants have been highly substituted by synthetic medicines in the Brazilian official medicine throughout the years.

Table 2 shows the evolution of the number of Monographs for native Brazilian plants in FBRAS. Among those 713 Monographs in the $1^{\text {st }}$ edition, 196 $(27,5 \%)$ refer to medicinal plants or botanical products native from Brasil. It can be shown that those species were included in the Pharmacopoeia due their successful use by physicians and pharmacists at that time. The $2^{\text {nd }}$ edition included 205 Monographs for medicinal plants and products, $32(15,6 \%)$ of them referring to Brazilian Native plants and products. Among the 23 Monographs for vegetal products included in the $3^{\text {rd }}$ edition, only 4 $(17,4 \%)$ refer to Brazilian Native plants, while all the other Monographs refer to exotic or imported species. In FBRAS's $4^{\text {th }}$ edition, the first Monographs for vegetal drugs were only published in 1996 and today it includes 44 Monographs, $11(25 \%)$ of which referring to Native Brazilian medicinal plants and products.

\section{CONCLUSION}

Our survey showed a strong substitution of medicinal plantas and other native products of Brazil by synthetic products and foreign plants within FBRAS in the last decades. It shows how biodiversity and native plants and products are being progressively excluded from Brazil's official medicine throughout the years. The Fourth Edition includes a larger number of Monographs referring to native plants and products, but they are still of little significance in the face of the vast available and acknowledged biodiversity and the extremely rich and still unknown traditional medicine. Special efforts are urgently necessary to validate and protect these plants. 


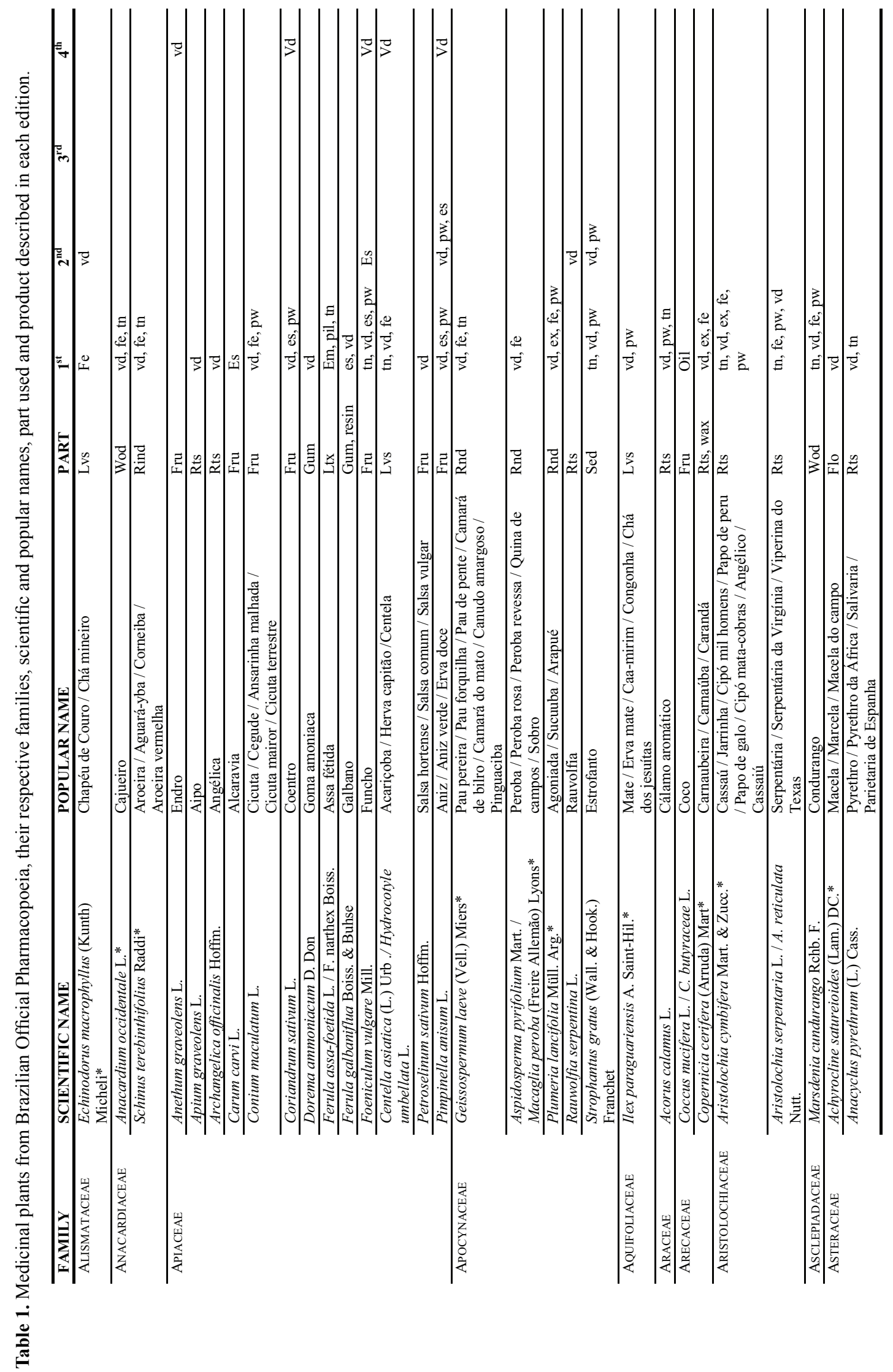




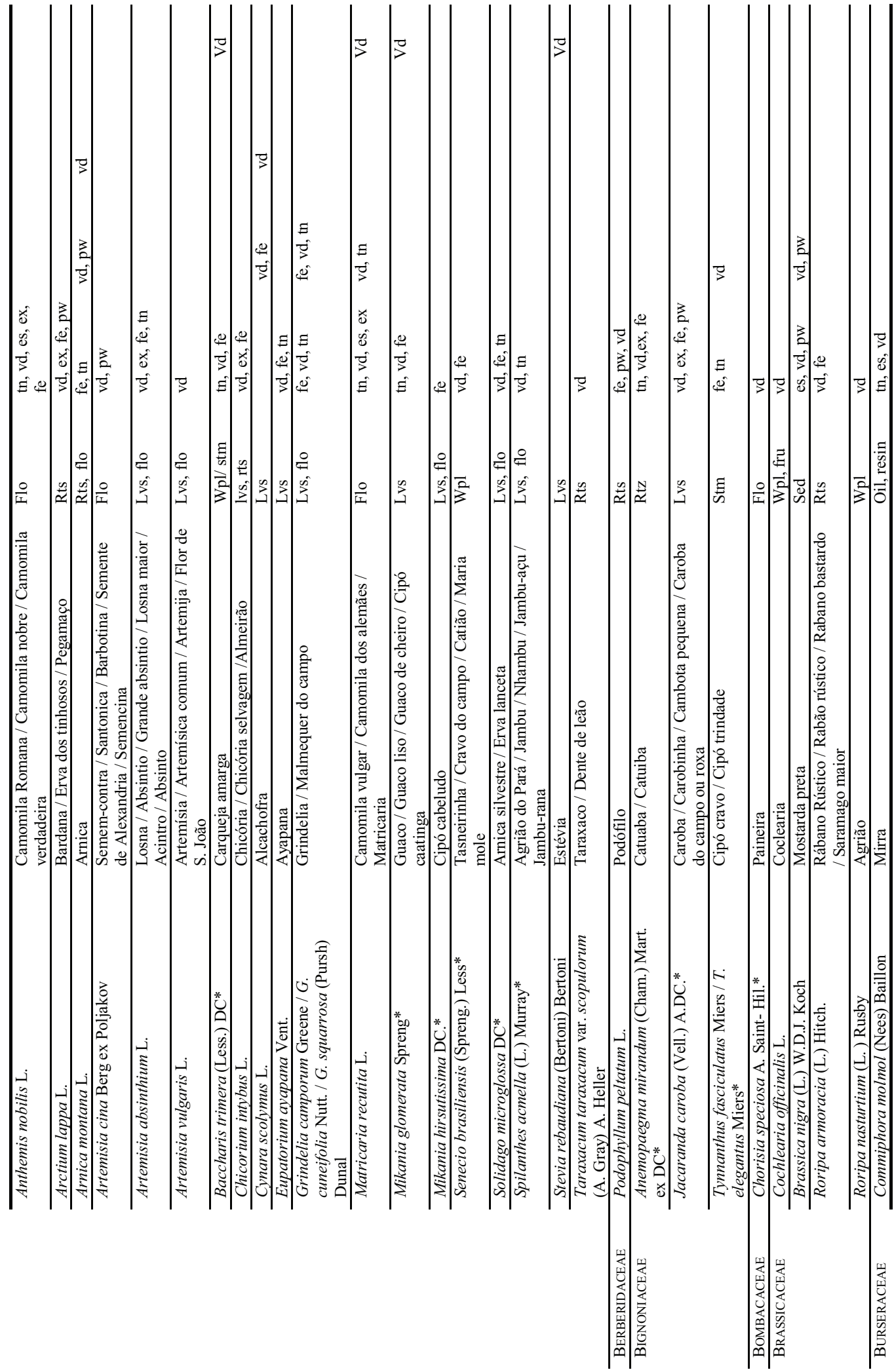



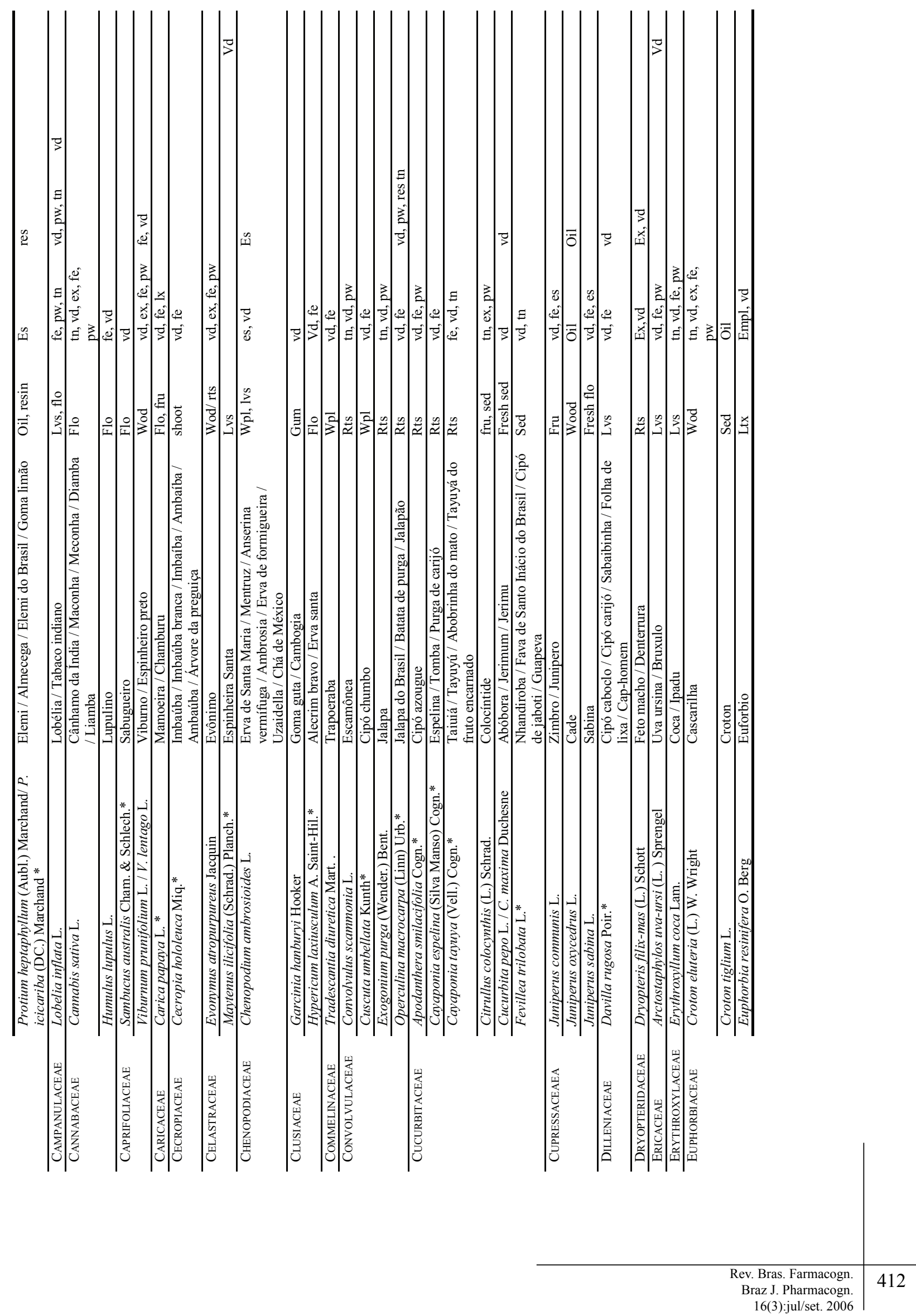


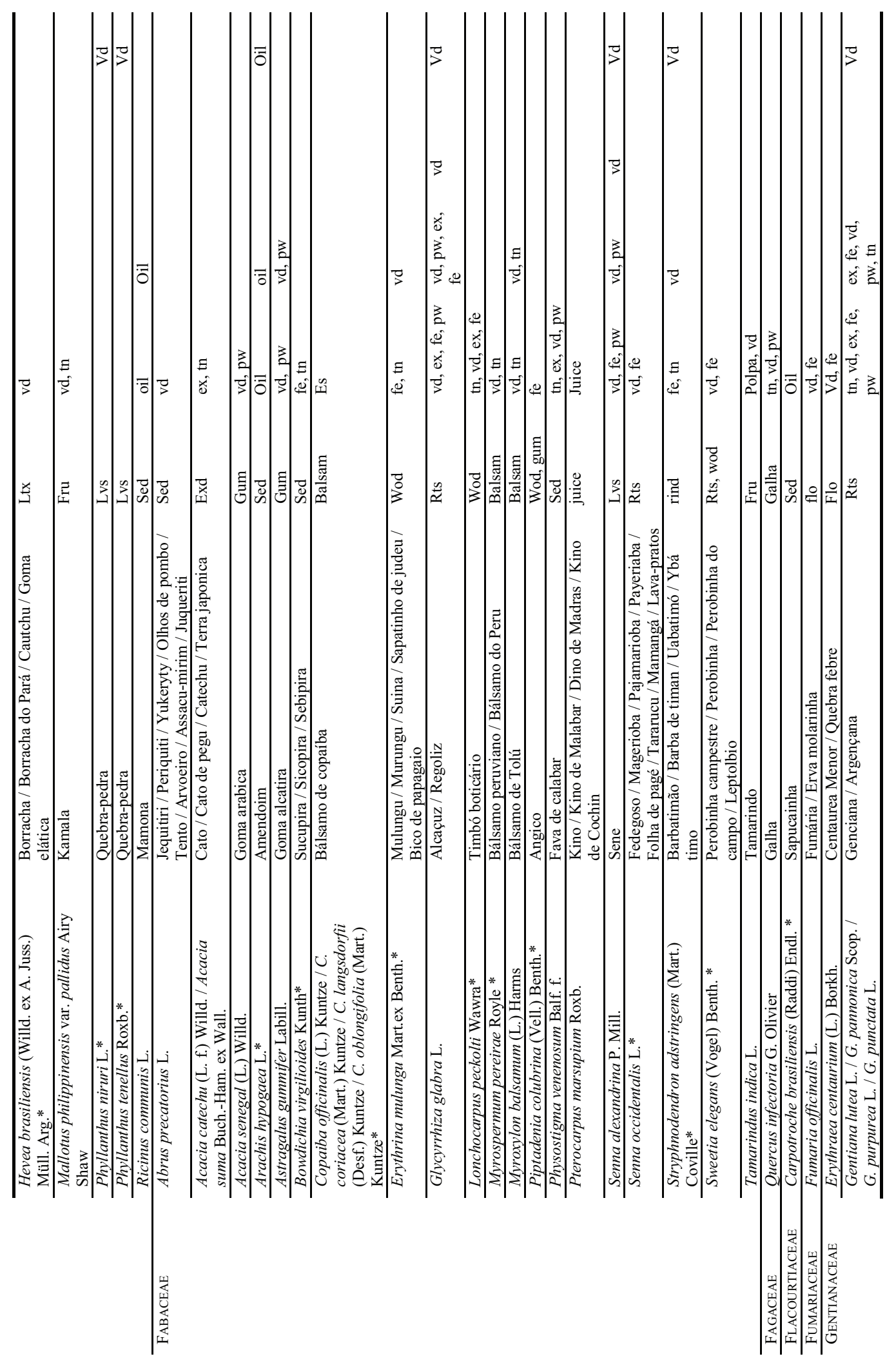




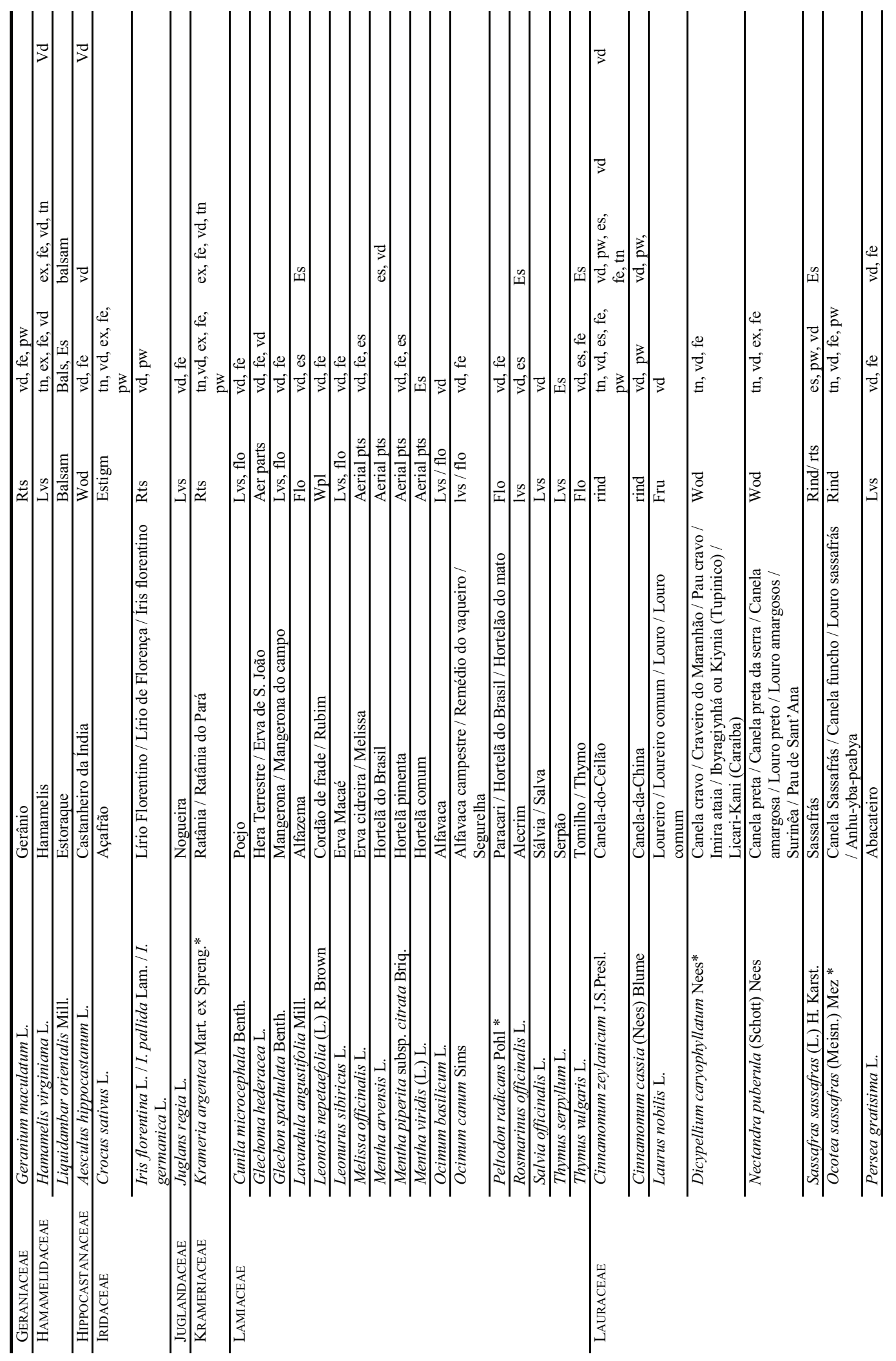




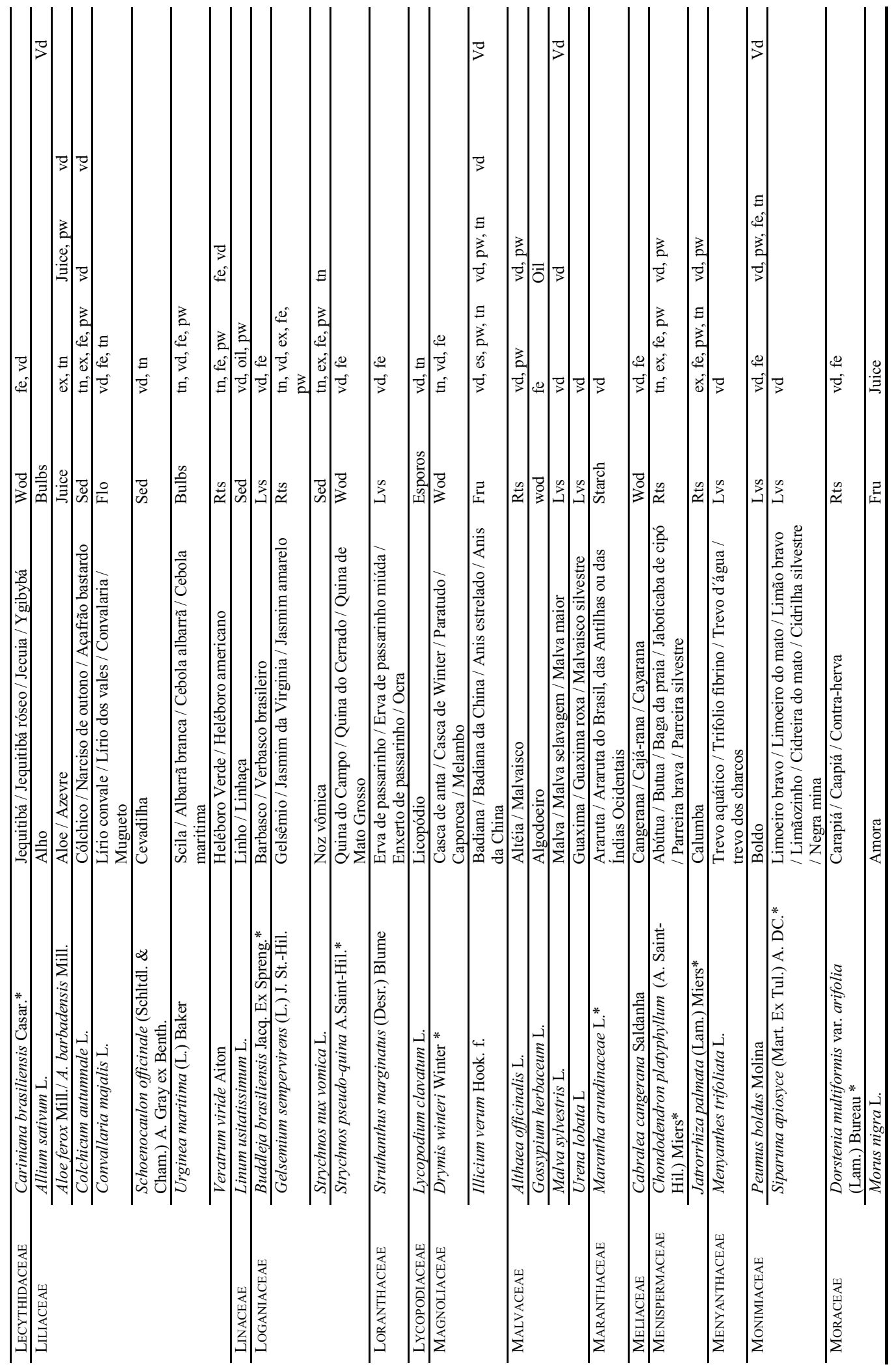




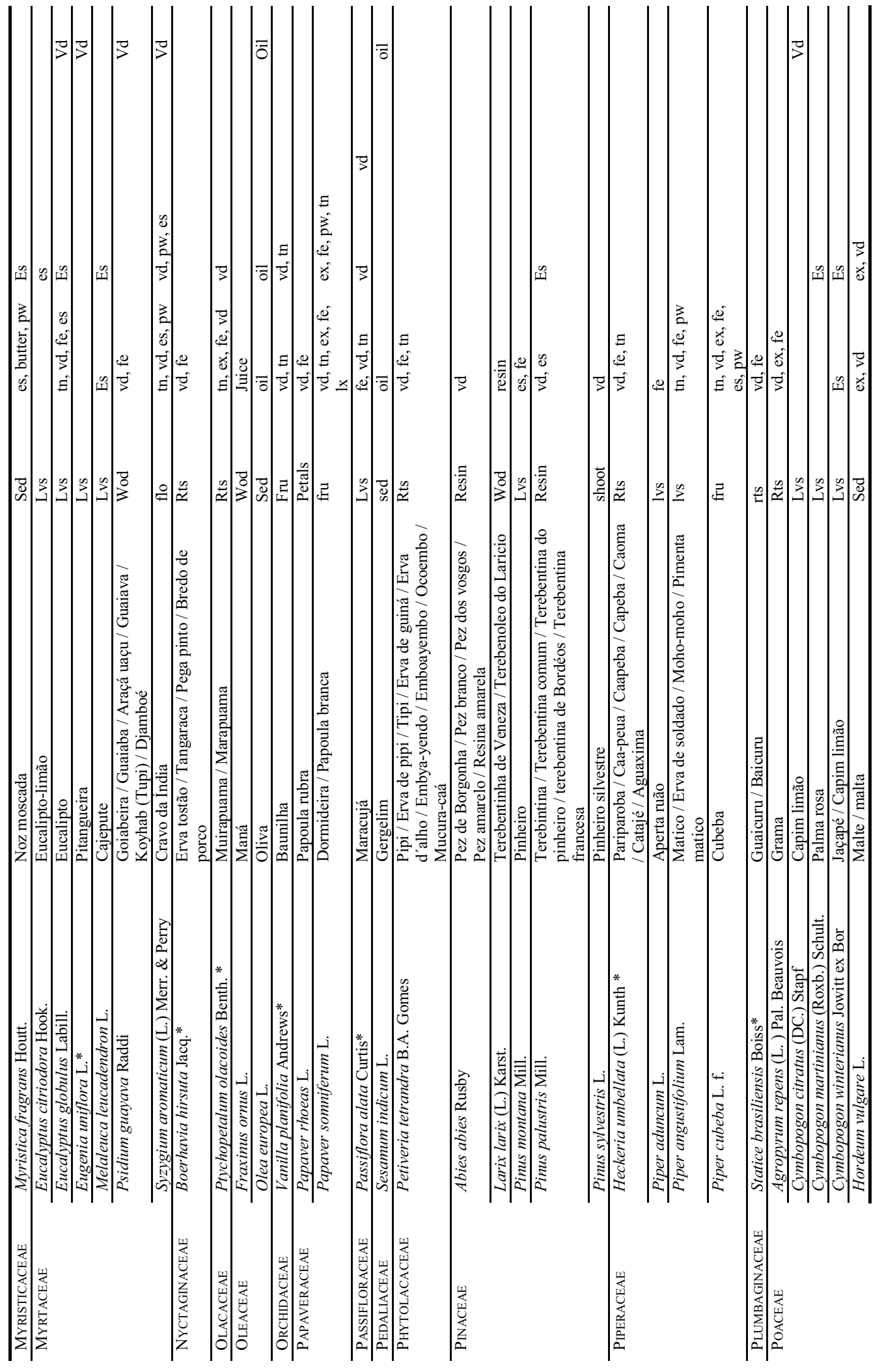




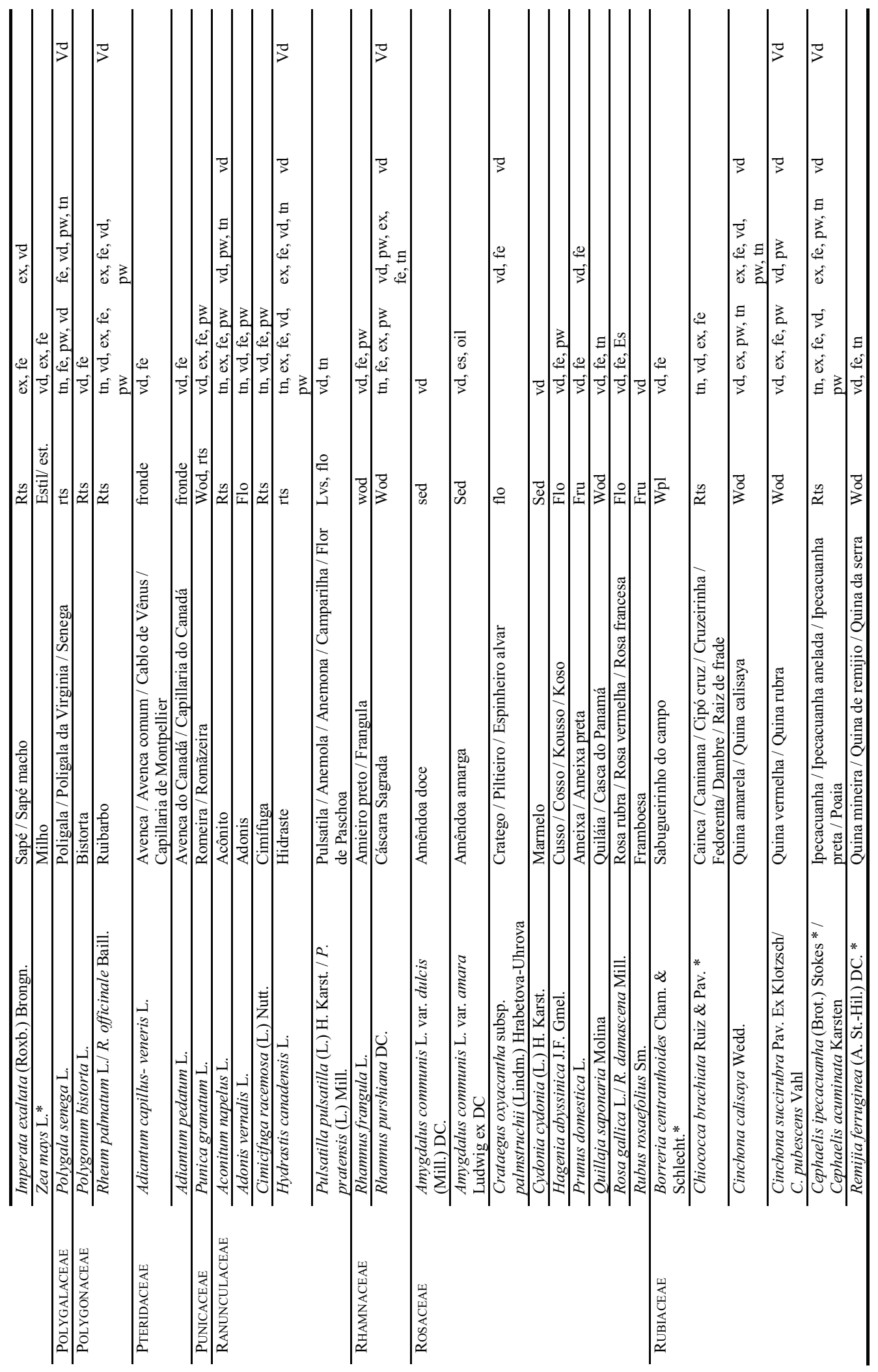



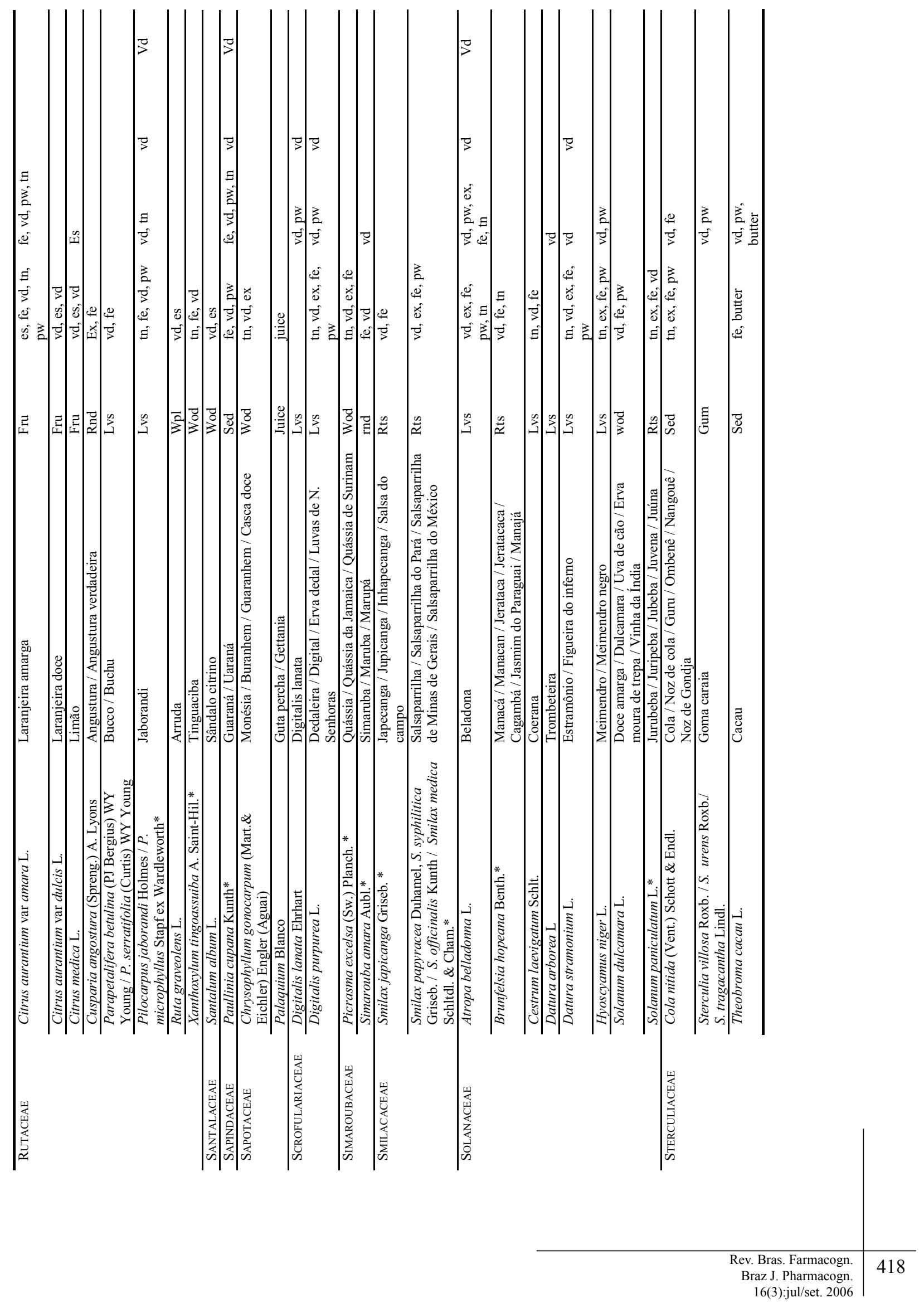


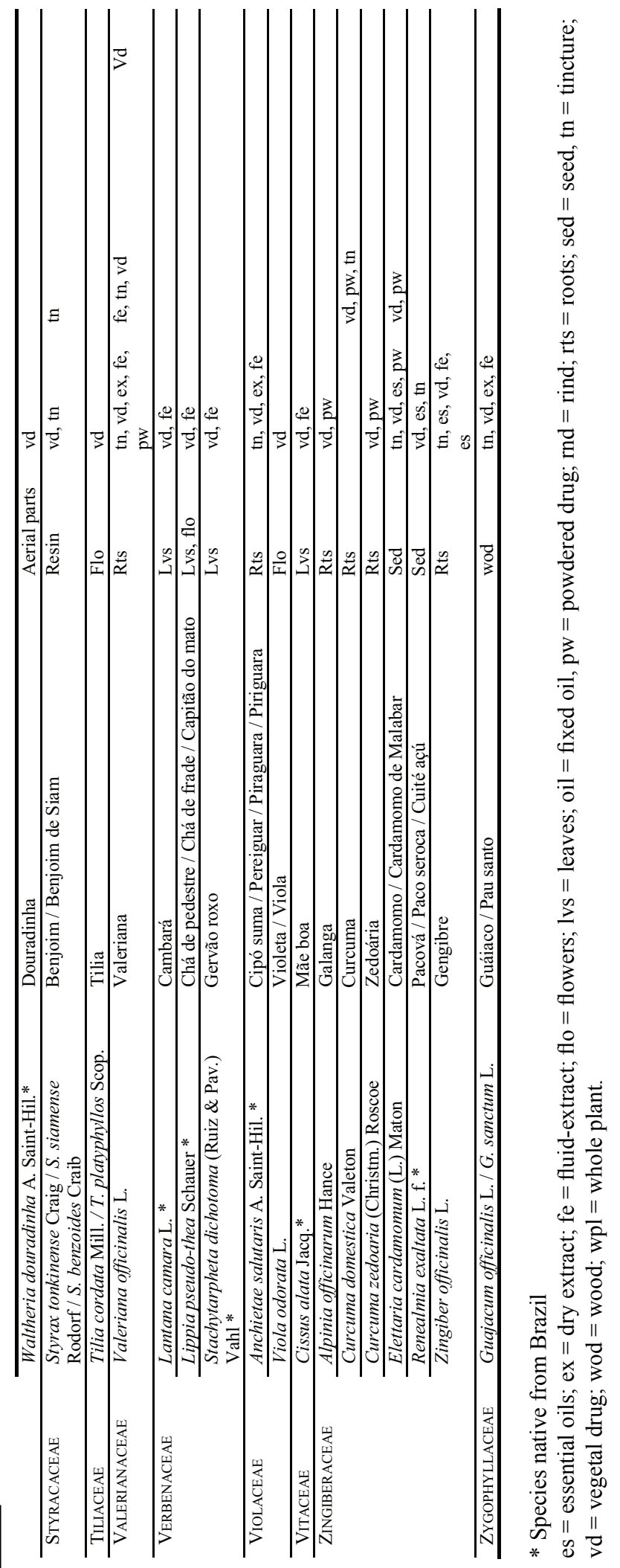


Table 2. Number of monographs for native species in each edition of Brazilian Official Pharmacopoeia

\begin{tabular}{lccc}
\hline Edition of & \multicolumn{3}{c}{ Number (\%) of Monographs } \\
\cline { 2 - 4 } Pharmacopoeia & Native & Others & Total \\
\hline $1^{\text {st }}$ edition $(1926)$ & $196(27,5)$ & $517(72,5)$ & 713 \\
\hline $2^{\text {nd }}$ edition $(1959)$ & $32(15,6)$ & $173(84,4)$ & 205 \\
\hline $3^{\text {rd }}$ edition $(1977)$ & $4(17,4)$ & $19(82,6)$ & 23 \\
\hline $4^{\text {th }}$ edition $(1996)$ & $11(25)$ & $33(75)$ & 44 \\
\hline
\end{tabular}

\section{REFERENCES}

Burton R 1977. Viagem de canoa de Sabará ao oceano atlântico. São Paulo: Ed. Itatiaia.

Casamada RSM 1977. Tratado de Farmacognosia. Barcelona: Editorial Cientifico Medica.

Costa AF 1996. Farmacognosia. Lisboa: Fundação Calouste Gulbekian. vols I and II.

Dean W 1996. A ferro e fogo: a história e a devastação da Mata Atlântica brasileira. São Paulo: Companhia das Letras.

Farmacopeia Brasileira 1959. 2.ed. São Paulo: Indústria Gráfica Siqueira.

Farmacopeia Brasileira 1977. 3.ed. São Paulo: Organização Andrei.

Farmacopeia Brasileira 1988-1996. 4.ed. São Paulo: Atheneu.

Figueiredo BG 2002. A arte de curar: cirurgiões, médicos, boticários e curandeiros no século XIX em Minas Gerais. Rio de Janeiro: Vício de Leitura.

Godoy MM 1996. Dicionário das viagens em Minas Gerais no século XIX. Varia História 15: 161-192.

Golse J 1955. Précis de Matière Médicale. Paris: G.Doin \& Co.

Gilg E, Brendt W, Schürhoff PM 1942. Farmacognosia. Barcelona: Editorial Labor.

Mawe J 1978. Viagens ao interior do Brasil. Belo Horizonte: ed. Itatiaia; São Paulo: ed. da Universidade de São Paulo

Pharmacopoeia dos Estados Unidos do Brasil 1926. 1.ed. São Paulo: Nacional.

Pohl JE 1976. Viagem no interior do Brasil. Belo Horizonte: Ed. Itatiaia; São Paulo: Ed. da Universidade de São Paulo.

Saint-Hilaire A 1974. Viagem pelo Distrito dos Diamantes e litoral do Brasil. Belo Horizonte: ed. Itatiaia; São Paulo: ed. da Universidade de São Paulo.

Silva DB 1997. Diários de Langsdorff. Rio de Janeiro: ed. FIOCRUZ.

Spix JB 1981. Viagem pelo Brasil: 1817 - 1820 / Spix e Martius. Belo Horizonte: Ed. Itatiaia; São Paulo: Ed. da Universidade de São Paulo.

Youngken HW 1943. Text-Book of Pharmacognosy. Philadelphia: The Blakinston Co.

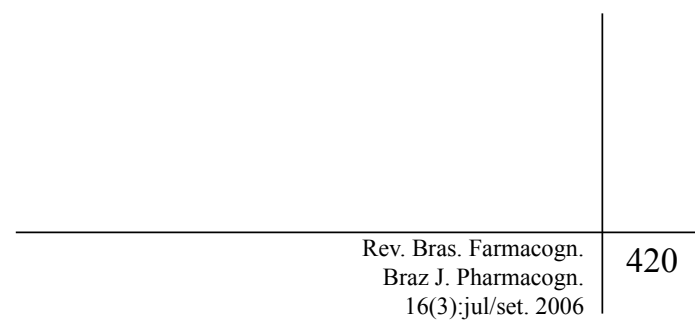

